\title{
Saliva as a diagnostic fluid in sports medicine: potential and limitations
}

\author{
Saliva como fluido diagnóstico para utilização na medicina esportiva: \\ potencialidades e limitações
}

Lázaro Alessandro Soares Nunes'; Denise Vaz de Macedo²

\begin{abstract}
The use of saliva in the diagnosis of pathologies and/or monitoring of athletes in competitions or trainings is an attractive alternative due to the fact that samples are easily obtained and it is mostly a less invasive method in comparison with venous blood collection. The saliva is a hypotonic fluid in relation to plasma, containing compounds produced in the salivary glands (immunoglobulin A [IgA] and $\alpha$-amylase) as well as compounds diffused in the plasma (water, electrolytes, proteins, metabolites and hormones). It plays a pivotal role in the protection of oral mucosa against microbes and in food digestion. Its production and composition depend on the sympathetic and parasympathetic nervous system activity, whose antagonistic action may result in different saliva volumes with distinct ionic and protein profiles. The aim of this review was to present a critical analysis of the potential and limitations of saliva as a diagnostic tool in sports medicine. Although there are studies that have deployed it to monitor athletes in training and doping, the standardization of some preanalytical variables are still required, among which the following ones are worth mentioning: the accurate choice of collection system, which allows the easy quantification of volume with adequate sample recovery; well-defined collection schedules in accordance with the circadian variations of the analyte; prevention of sample contamination with blood from oral mucosa lesions. Another key point for its application in sports is the establishment of reference intervals for analytes quantified in the saliva, collected from a population that comprises healthy individual that exercise regularly and systematically, with physical activity progression.
\end{abstract}

Key words: oral fluid; saliva collection; preanalytical variation; exercise; reference values.

\section{INTRODUCTION}

The need to collect venous blood samples at different moments of the season represents a drawback to laboratory monitoring, insofar as the procedure is uncomfortable for many athletes. A previous article from our laboratory demonstrated that fingerprick may be an interesting alternative to venipuncture ${ }^{(44)}$. This technique is less invasive and less stressful, enabling the monitoring of athletes during and after physical tests, training or competition, without major changes in routine. Furthermore, the currently available automated pieces of equipment allow the use of increasingly lower sample volumes, enabling the analysis of blood samples in microtubes ${ }^{(44)}$. However, some individuals have reported some discomfort with the procedure.

The interest in less invasive biological fluids instead of blood has grown exponentially in recent years ${ }^{(21)}$. In this context, the saliva is a biological fluid that has some distinct advantages: it is a non-invasive procedure, which requires relatively simple instructions for collection. Moreover, it does not pose major risks during collection, allowing a safer management ${ }^{(30)}$.

Some studies have assessed the saliva in the diagnosis and monitoring of renal disease ${ }^{(8)}$, metabolic disorders ${ }^{(56)}$, detection and quantification of viral nucleic acids ${ }^{(50)}$ and therapeutic drug

First submission on 21/12/12; last submission on 08/02/13; accepted for publication on 02/04/13; published on 20/08/13

1. Doctor in Functional and Molecular Biology (Biochemistry area) by Universidade Estadual de Campinas (UNICAMP)-Biology Institute; associate researcher at the Exercise

Biochemistry Laboratory (Laboratório de Bioquímica do Exercício [LABEX]) from UNICAMP-Biology Institute; professor of Biomedical Sciences at Faculdade Integrada Metropolitana de Campinas (METROCAMP).

2. Doctor in Biochemistry by UNICAMP; associate professor at LABEX Biochemistry Department from UNICAMP-Biology Institute. 
monitoring ${ }^{(32)}$. There are also some studies proposing the use of saliva in the monitoring of athletes in exercise situations and doping $^{(12,42,55,59)}$.

We believe, however, that the standardization of major preanalytical variables is still required, of which the following may be highlighted: the accurate choice of collection system, which allows to quantify the volume easily, with good sample recovery; well defined collection schedules in accordance with possible circadian variations of the analyte; the prevention of sample contamination with blood from oral mucosa lesions. The objective of this review was to conduct an analysis of the potentialities and limitations of the use of saliva as diagnostic fluid in sports medicine.

\section{PRODUCTION OF SALIVA}

The fluid present in the oral cavity originates mainly from three salivary glands: parotid, submandibular and sublingual. Additionally, other minor glands and gingival crevicular fluid may contribute, albeit in small volume, to the formation of what is designated as "oral fluid" or "whole saliva"(27).

Each salivary gland secretes a characteristic type of saliva, with different ionic $^{(29)}$ and protein ${ }^{(15)}$ concentrations. Adults normally produce 0.5 to 1.51 of saliva daily ${ }^{(11)}$. The production of saliva varies if the individual is not provided with stimulation (submandibular $=65 \%$, parotid gland $=20 \%$, sublingual $=5 \%$ and minor glands $=10 \%$ ) in comparison with artificial stimulation when the parotid gland contributes to over $50 \%$ of total salivary secretions $^{(27)}$. Under normal conditions, the unstimulated saliva presents a secretion rate of approximately $0.1 \mathrm{ml} / \mathrm{min}$, reaching a peak of $7 \mathrm{ml} / \mathrm{min}$ when artificially stimulated ${ }^{(27)}$. During and after high intensity exercise (above the anaerobic threshold), the secretion of saliva decreases, mainly due to adrenergic action, dehydration or evaporation ${ }^{(11)}$.

The salivary glands comprise acinar cells, duct cells and myoepithelial cells irrigated by capillary networks (Figure). In acinar cells, the primary saliva is secreted as an isotonic fluid in relation to plasma ${ }^{(2)}$. Depending on the original gland, this secretion may be serous (parotid), mucous (minor glands) or mixed (sublingual and submandibular) ${ }^{(27)}$. The various acini are connected by intercalated ducts and the secreted saliva is drained to the oral cavity through striated and excretory ducts.

The flow of plasma components into the saliva may involve several processes (Figure): (a) ultrafiltration through gap junctions between secretory cells. In this case, only molecules with a molecular weight below $1.9 \mathrm{kDa}$ can be transported (ions, water, and some hormones); (b) selective transport through passive diffusion of lipophilic molecules (steroid hormones); (c) active transport through ion channels; (d) active pumping of $\mathrm{Na}^{+}$ions with concomitant entrance of $\mathrm{H}_{2} \mathrm{O}$.

The saliva also contains compounds that are synthesized primarily in acinar cells and, to a lesser extent, in duct cells (e). That is to say that some saliva components are not related to plasma concentrations, but they are related to the local glandular answer. Furthermore, the concentration of numerous electrolytes changes due to active ion transport (f), hence saliva has a hypotonic characteristic in relation to blood ${ }^{(2,27)}$.

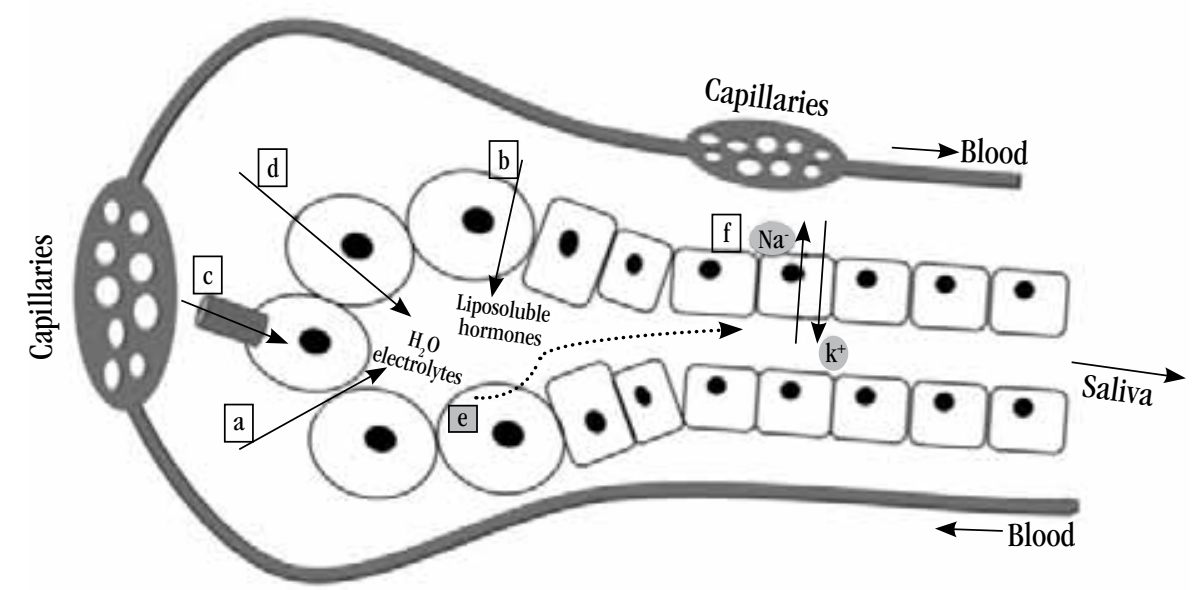

FIGURE - Transport mechanism of plasma components into the salivary gland

(a) entry of components by simple filtration; (b) entry of liposoluble compounds by passive diffusion; (c) entry of components by active transport; (d) active pumping of $\mathrm{Na}^{+}$ions and concomitant entry of $\mathrm{H}_{2} \mathrm{O}$; (e) component produced and secreted by the salivary glands; (f) pumping of Na+ions into the blood, producing hypotonic fluid. Adapted from Wong, D. T. $(2006)^{(60)}$. 
Other elements such as bacteria, epithelial cells, erythrocytes, leukocytes, food debris or contamination from gingival crevicular fluid (due to gingival inflammation) may also be present in saliva. This fact cannot be neglected, since it may cause several interferences in analytical assays ${ }^{(2,10,30)}$.

\section{FUNCTIONS AND REGULATION}

The components present in the saliva play several vital roles in the oral mucosa immunity (immunoglobulin A [IgA], mucins and cystatins), in the protection of teeth against the action of microorganisms (lysozyme, lactoferrin, histamine) ${ }^{(43)}$, in food digestion (alpha-amylase and protease) ${ }^{(33)}$ and in the buffering of acidic substances (bicarbonate, phosphate and proteins) ${ }^{(10)}$. Several physiologic or pathologic factors may alter the production of saliva quantitatively and qualitatively, for instance, mastication, psychological factors, medication, age, oral hygiene ${ }^{(2)}$ and physical activity $(1,11)$.

The flow and composition of saliva are regulated mainly by the activity of the autonomic nervous system: the serous glands are controlled by the sympathetic nervous system and seromucous glands by both sympathetic and parasympathetic systems. $\alpha$ or $\beta$-adrenergic stimulation (neural/pharmacological) may modify the quantity, viscosity, protein and ionic concentrations of the saliva ${ }^{(2,10)} \cdot \alpha$-adrenergic stimulation causes calcium influx into the secretory cells, which results in liquid with high protein concentration. Due to the low presence of mucins, this type of saliva presents low volume and viscosity ${ }^{(2)}$, whereas $\beta$-adrenergic stimulation results in fluid with high protein content, high viscosity, low volume and foamy appearance ${ }^{(10)}$.

The mucous glands receive only cholinergic stimulation (parasympathetic). This type of stimulation results in aqueous saliva, with high volume, rich in electrolytes, low viscosity and low protein concentration ${ }^{(2)}$. Thus, it is important to consider the influence of the circadian cycle on some saliva constituents when interpreting results ${ }^{(45)}$.

\section{CONSTITUENTS OF THE SALIVA}

\section{Proteins and enzymes}

Mucins are virtually secreted by all salivary glands. They play a fundamental role in their rheological properties such as viscosity and elasticity. Many other proteins have been identified and studied through comprehensive analytical techniques such as proteomics ${ }^{(26)}$ or specific methods such as capillary electrophoresis, mass spectrometry, radioimmunoassay (RIA), enzyme immunoassay (ELISA) and liquid chromatography ${ }^{(14,15,25)}$. Among these proteins, we highlight the following ones: prolinerich protein (PRP), albumin, immunoglobulins, lysozyme, lactoferrin, lactoperoxidase, histatins and $\alpha$-amylase ${ }^{(26)}$. Apart from the action of the autonomic nervous system ${ }^{(40)}$, some diseases such as cystic fibrosis, diabetes ${ }^{(51)}$, cancer $^{(28)}$ and epilepsy seem to alter the salivary protein profile ${ }^{(2)}$. Recent investigations into the proteome of saliva from individuals with type II diabetes demonstrated significant rises in the expression of proteins related to the metabolism and immune system in comparison with saliva from non-diabetic subjects ${ }^{(51)}$. These studies may provide information on the development of new tests for early diagnosis of cancer, diabetes and other pathologies ${ }^{(28)}$.

Exercising may also alter saliva protein content. Among the most abundant salivary proteins in the sports area are the salivary $\alpha$-amylase (AAS) and IgA, which play a key role in oral mucosa immunity ${ }^{(4,33)}$. IgA is synthesized by B lymphocytes in the periphery of the secretory epithelium, transported through the cell membrane of the salivary cells and then secreted in the saliva $a^{(4)}$.

The salivary IgA is widely studied as a marker of immune system function, predominating in mucosa secretions ${ }^{(18)}$. Its function is to provide the first line of defense, acting against the adhesion and penetration of microorganisms in the mucosa ${ }^{(4)}$. Furthermore, it disrupts the replication of pathogens by intracellular neutralization, binding to antigens in order to facilitate its removal from the epithelium ${ }^{(4)}$. Individuals who have IgA deficiency and low salivary flow commonly present a high incidence of respiratory infections in the upper tract ${ }^{(16)}$.

The results yielded by studies that assessed the effects of exercise on IgA concentrations are contradictory. Some studies reported a decrease after high intensity exercise sessions ${ }^{(42)}$, others did not report any change ${ }^{(36)}$ or increase ${ }^{(5)}$. When subjects are at rest, there is no difference between IgA levels in the saliva samples from athletes or sedentary individuals, with exception of those who are under intensive training ${ }^{(18)}$. The lack of standardization in collection, analysis and expression of the results yielded in these studies encumbers the comparison among them ${ }^{(4)}$.

SAA corresponds to approximately $40 \%$ to $50 \%$ of the total protein produced by the glands and released in the saliva ${ }^{(4)}$. It is synthesized chiefly by the parotid gland (80\%) and is involved in the digestion of carbohydrates and oral mucosa immunity ${ }^{(33)}$. Its release is conditioned to the activation of the autonomic nervous system through the action of $\alpha$ and $\beta$-adrenergic mediators ${ }^{(41)}$. Moreover, it may respond acutely to gustatory and mechanical stimuli caused by mastication ${ }^{(41)}$. 
More recently, SAA has been used as an indicator of physical ${ }^{(34)}$ and psychological stress ${ }^{(0,41)}$, inasmuch as its activity in saliva apparently correlates with serum levels of epinephrine and cortisol $^{(9)}$. Studies have shown that SAA activity increases in response to stressful conditions, such as exercise, heat, cold, and behavioral tests ${ }^{(0,20)}$.

It is worth noting that the peak of this enzyme is reached between 15 and 20 minutes before the rise in salivary cortisol concentration. This pattern is due to the response time of the sympathetic nervous system (SNS), which is faster when compared with the response of the pituitary-adrenal axis. $\alpha$-amylase is synthesized and secreted directly from the salivary gland into the oral cavity, whereas cortisol needs to be released by the adrenal gland, go through the circulation and then diffuse passively until reaching the saliva. This may be one of the reasons why some studies that evaluated stress did not reveal much correlation between $\alpha$-amylase and salivary cortisol ${ }^{(20)}$.

Another strong SNS activator able to alter the concentrations of $\alpha$-amylase in saliva is physical exercise. Several studies have demonstrated increases in the concentration of salivary $\alpha$-amylase during and after exercise in comparison with basal values ${ }^{(11,13)}$. In this context, Calvo et al.$^{(7)}$ proposed the use of SAA as an indicator of anaerobic threshold in incremental exercise on treadmill.

The enzyme $\alpha$-amylase is produced by the salivary gland along with other components of the saliva, therefore all factors that stimulate salivation may influence $\alpha$-amylase secretion. Additionally, the production of SAA follows the variation of the circadian cycle, hence its lower levels in the early morning with peak values between 4 and $\left.5 \mathrm{PM}^{(39}, 45\right)$. This implies that the influence of diet and circadian variation during the day should be contemplated when SAA is used in longitudinal studies ${ }^{(39,45)}$, always following the same sample collection schedule.

\section{Inorganic compounds}

The saliva contains mainly water and strong and weak ions $\left(\mathrm{Na}^{+}, \mathrm{K}^{+}, \mathrm{Mg}^{+}, \mathrm{Ca}^{2+}, \mathrm{Cl}\right.$, bicarbonate and phosphate), which may function as buffering agents. The electrolyte concentrations in the saliva may be quantified by flame photometry and ion-selective electrode. Table 1 shows reference intervals for some electrolytes in the saliva compared with plasma ${ }^{(52)}$.

$\mathrm{K}^{+}$concentration in saliva is well above the values observed in plasma. Conversely, the concentration of $\mathrm{Na}^{+}$and $\mathrm{Cl}$ in this fluid is lower in relation to plasma $a^{(2)}$. As a result of this difference in concentrations when analyzing potassium through ion selective electrode (ISE), the dilution of saliva samples is recommended. On the other hand, sample
TABLE 1 - Reference interval (2.5 to 97.5 percentile) for electrolytes measured in saliva collected by passive method and plasma

\begin{tabular}{cccc}
\hline Analyte & $n$ & $\begin{array}{c}\text { Salivary } \\
\text { concentration }\end{array}$ & $\begin{array}{c}\text { Plasma } \\
\text { concentration }\end{array}$ \\
\hline $\mathrm{Na}^{+}(\mathrm{mmol} / \mathrm{l})$ & 60 & $3-29$ & $136-145$ \\
$\mathrm{~K}^{+}(\mathrm{mmol} / \mathrm{l})$ & 60 & $6.4-36.6$ & $3.5-4.5$ \\
$\mathrm{Ca}^{2+}(\mathrm{mmol} / \mathrm{l})$ & 60 & $0.88-2.5$ & $1.15-1.33$ \\
$\mathrm{Cl}^{-}(\mathrm{mmol} / \mathrm{l})$ & 60 & $0-27$ & $98-107$ \\
\hline
\end{tabular}

Adapted from Rehak, N. N. (2000)(52).

dilution is not required to measure $\mathrm{Na}^{+}$and $\mathrm{Cl}$. Colorimetric methods or flame photometry are preferable, insofar as salivary concentrations are below the detection range reported by $\operatorname{ISE}^{(52)}$.

Physical exercise of varying intensity and duration may change saliva ionic concentration, especially $\mathrm{Na}^{+}$and $\mathrm{K}^{+(11)}$. The salivary concentrations of $\mathrm{Na}^{+}, \mathrm{K}^{+}$and $\mathrm{Cl}^{-}$appear to be linked with the lactate anaerobic threshold during incremental test on ergometric cycle ${ }^{(12)}$. These changes may be credited to sympathetic stimulation, which induces changes in salivary flow, reabsorption and secretion of electrolytes in the secretory cells ${ }^{(11)}$.

\section{Non-protein organic compounds}

Some non-protein organic compounds may be found in low concentrations in the saliva. They fulfill different functions and mostly originate from the plasma by ultrafiltration. They may be occasionally present due to contamination with blood from lesions of the oral mucosa. Thus, negligible amounts of bilirubin, creatinine, glucose, cholesterol and triglycerides may be detected in the saliva from healthy individuals ${ }^{(52)}$.

The salivary concentrations of urea $(2.9 \text { to } 6.8 \mathrm{mmol} / \mathrm{l})^{(52)}$ and uric acid $(0.07-32 \mathrm{mmol} / \mathrm{l})^{(45)}$ correspond to metabolic changes resulting from pathologies such as renal dysfunction and gout. In individuals with renal involvement, salivary concentrations of urea may rise dramatically (from 6.1 to $29.6 \mathrm{mmol} / \mathrm{l}$ ), following plasma levels ${ }^{(8)}$

Uric acid is the major antioxidant present in the saliva and contributes to approximately $70 \%$ of the total antioxidant capacity ${ }^{(38)}$. Its quantification has been deployed in monitoring the effects of hemodialysis ${ }^{(6)}$ and in the assessment of patients with gout ${ }^{(47)}$. Acute exercise promotes increases in salivary uric acid levels ${ }^{(1,47)}$ and total antioxidant capacity when compared with baseline ${ }^{(19)}$. Nevertheless, Youssef et al. ${ }^{(61)}$ demonstrated that the total salivary antioxidant capacity of triathletes fell significantly by the end of the season when the values were compared with the beginning of the training period. Other important organic 
molecules such as ascorbic acid and vitamin E make up the salivary antioxidant defense system ${ }^{(38)}$.

Automated spectrophotometric techniques that evaluate non-enzymatic salivary antioxidant capacity may be useful for monitoring athletes due to its non-invasive nature. However, specific salivary reference values are required, insofar as there is no significant correlation between the antioxidant capacity in saliva and plasma ${ }^{(45)}$.

Another important compound to be applied in sports is lactate. Some studies analyzed the salivary lactate response to exercise in an attempt to determine the intensity of training or assess the correlation between blood and salivary lactate ${ }^{(11,40)}$. No change was observed in salivary lactate during aerobic exercise compared with rest period.

\section{HORMONES}

Most hormones present in the plasma may be measured in the saliva due to a connection between plasma and salivary glands ${ }^{(10)}$. The primary entry route of steroid hormones and other small and neutral molecules in the saliva is through passive diffusion. The salivary glands are intensively irrigated by capillary networks and many of the liposoluble blood components easily pass through the capillary walls into the salivary glands ${ }^{(21)}$.

Serum proteins and globulins that bind to hormones are large molecules that do not pass through the cell membranes of salivary glands. Accordingly, only unbound hormones (free fraction) present in plasma may diffuse into saliva. Thus, unconjugated steroid hormones (such as cortisol, estriol, progesterone and testosterone) diffuse predominantly intracellularly, do not influence salivary flow and present very similar concentrations of free plasma fraction ${ }^{(58)}$.

On the other hand, electrically charged steroids or those conjugated with proteins are able to pass, albeit in small quantities, through the gap junctions between salivary gland cells. As this process is very slow, these hormones tend to have their values strongly affected by salivary flow, with much lower concentrations in relation to plasma ${ }^{(58)}$. It is particularly worth mentioning that these analyzes may encounter interference due to contamination with blood. Small amounts of blood originated from oral and gingival lesions may cause false rises in the concentrations of salivary analytes ${ }^{(54)}$.

Cortisol is a hormone produced by the adrenal glands and released into the circulation. It has important metabolic functions, such as controlling blood pressure, cardiovascular function and immune system ${ }^{(53)}$. In peripheral tissues, cortisol stimulates lipolysis, increases protein degradation and lowers protein synthesis in muscle cells, resulting in higher release of amino acids and lipids in the circulation ${ }^{(31)}$. The secretion of this hormone undergoes circadian variation, with higher concentrations in the morning and lower concentrations in the afternoon ${ }^{(39)}$. Some studies reveal that the free fraction in plasma cortisol correlates with salivary concentrations ${ }^{(35,58)}$, enabling the use of this marker in the assessment of responses to physical and psychological stress ${ }^{(53)}$.

Physical activity is able to raise dramatically the concentration of salivary cortisol in athletes subjected to different forms of exercise $^{(3)}$. In addition to evaluating the adaptive responses to training, cortisol may be an interesting biomarker to investigate the levels of tolerance or intolerance to training when performed in conjunction with testosterone measurement and subsequent calculation of testosterone: cortisol ratio ${ }^{(57)}$.

Despite the convenience of the use of salivary cortisol in the assessment of athletes and patients with pathologies that alter the secretion of corticosteroids, caution is required in interpreting data obtained with saliva samples. Few studies establish reference values for salivary cortisol considering circadian variation and in accordance with the protocol proposed by the International Federation of Clinical Chemistry (IFCC) ${ }^{(48)}$.

Other synthetic or natural androgenic hormones that are administered illegally with the aim to improve performance may diffuse passively into the saliva ${ }^{(58)}$. Although it is possible to quantify testosterone, epitestosterone, tetrahydrogestrinone and other hormones used by athletes for illicit purposes, the World Anti Doping Agency (WADA) provides no information on the use of saliva in the detection and control of doping ${ }^{(21)}$.

\section{METHODS FOR SALIVA COLLECTION}

Saliva can be easily collected through passive drool directly into plastic tubes (unstimulated saliva). The passive collection is the most recommended method, inasmuch as most analytes may be quantified without hindrances. However, the supplied volume is low in this case ${ }^{(10)}$. Neither teeth brushing nor food and liquid ingestion (except water) are recommended for at least 30 minutes prior to collection. Mouth cleaning with water (preferably distilled) helps to eliminate residues that may hamper the analysis ${ }^{(10)}$.

The stimulated saliva may be collected through gustatory stimulation, mastication or the use of citric acid ${ }^{(30)}$. There are some commercial devices that facilitate saliva collection. Most of them contain a solid base, usually consisting of a small piece of cotton or polyester for saliva absorption and a conical tube for centrifugation 
and recovery of the collected liquid. Among the most common commercial systems that use solid bases are: Oral Salimetrics Swab (Salimetrics ${ }^{\circledR}$ LLC) Salivette ${ }^{\circledR}$ and Cortiso ${ }^{\circledR}$ Salivette (Sarstedt, Newton, NC) and Orapette (Trinity Biotech, Dublin, Ireland) ${ }^{(22)}$.

None of the collection systems mentioned above allow direct and accurate volume quantification, which is a common drawback. Furthermore, saliva and analyte recovery may vary considerably in each method, mainly owing to the fact that some analytes may adhere to the cotton, causing false lower values ${ }^{(14,22,37)}$.

Another currently available collection system is the Saliva Collection System $(\mathrm{SCS})^{\circledR}$ (Greiner Bio-One, GmgH, Kremsmuenster, Austria), which uses a buffered base of citric acid for saliva collection. This collection system is more elaborate and presents a solution for oral cavity cleaning and standardization of collection procedures. After applying a cleaning solution, the individual places the extracting solution in their mouth for 2 minutes and then spits out all the solution into a beaker. The collected saliva (saliva + extraction solution) is subsequently transferred via vacuum system to graduated transport tubes, which permit to quantify the total volume of collected solution ${ }^{(22,45)}$.

This system of saliva collection has been recently tested using routine laboratory methods and has demonstrated reliable and reproducible results for measurement of calcium, magnesium ${ }^{(49)}$, $\alpha$-amylase, uric acid ${ }^{(45)}$, IgA, cortisol and therapeutic drugg( ${ }^{(22)}$. Nonetheless, certain analytes are prone to interference due to $\mathrm{pH}$ and additives present in the extraction solution ${ }^{(45)}$. Compared with other commercially available systems, SCS requires further care during the collection so that there is no exchange of washing and extraction solutions. Moreover, it is highly costly ${ }^{(22)}$.

\section{Pre-analytical and analytical interferences in the analysis of saliva samples}

One of the most important pre-analytical interferences to be considered is the need to quantify time and volume of collected saliva in order to estimate the saliva secretion rate. The saliva flow rate through the salivary ducts determines, for instance, the concentration of electrolytes. The increase in salivary flow through artificial stimulation may change the ionic composition, raising concentrations of $\mathrm{Na}^{+}, \mathrm{Cl}^{-}$and bicarbonate and reducing salivary $\mathrm{K}^{+(2)}$. Some salivary components such as IgA and dehydroepiandrosterone-sulfate (DHEA-S) are dependent on salivary flow, requiring correction according to volume and collection time ${ }^{(2,58)}$.

The use of citric acid and chewing gum as stimulation and materials with cotton or polyester may inaccurately augment salivary testosterone levels. The use of collection devices with cotton is not recommended for the analysis of hormones due to the possibility of interference in the performance of immunoassays ${ }^{(21)}$. Cotton may bind to cortisol and dehydroepiandrosterone (DHEA) and cause a false decrease ${ }^{(17,23)}$.

Besides the choice of a suitable collection system, the collection time should always be standardized and observed. Hormones and other saliva constituents may present major circadian variations, which may require a pre-established collection schedule.

Table 2 shows that the reference interval for salivary cortisol may vary with the method or time of collection. The intake of alcohol, caffeine and protein-rich diets may alter cortisol levels ${ }^{(24)}$.

Saliva samples should be refrigerated $\left(4^{\circ} \mathrm{C}\right)$ if they are processed within 3 to 6 hours after collection. When the sample is stored for long periods, the temperature should be kept at $-80^{\circ} \mathrm{C}$ to prevent bacterial growth ${ }^{(24)}$. The salivary cortisol is stable at $5^{\circ} \mathrm{C}$ for three months and up to one year when stored within $-20^{\circ} \mathrm{C}$ to $-80^{\circ} \mathrm{C}$. Repeated freezing and thawing cycles do not affect cortisol concentrations ${ }^{(24)}$. The addition of sodium azide in saliva may inhibit bacterial growth and preserve the sample, though immunoassays using horseradish peroxidase may be subject to interference ${ }^{(10)}$.

TABLE 2 - Reference intervals for salivary free cortisol at different collection periods

\begin{tabular}{|c|c|c|c|c|c|}
\hline Collection method & Absorbing material & Salivary free cortisol (nmol/l) & $n$ & Observations & References \\
\hline PD & Polystyrene tubes & $10.9-40.3$ & 128 & $\begin{array}{l}\text { Collection (6h-8h); } \\
\text { RIE method }\end{array}$ & 48 \\
\hline SS & Cotton, Salivette $^{\circledR}$ & $3.57-35.1$ & 120 & $\begin{array}{l}\text { Collection (5h30-7h30); } \\
\text { RIE method }\end{array}$ & 23 \\
\hline SS & Cotton, Salivette ${ }^{\circledR}$ & $7.61-39.4$ & 119 & $\begin{array}{l}\text { Collection } 20 \text { minutes after } \\
\text { wake up; RIE method }\end{array}$ & 23 \\
\hline SS & Cotton, Salivette ${ }^{\circledR}$ & $1.14-10.3$ & 96 & $\begin{array}{l}\text { Collection (18h); } \\
\text { RIE method }\end{array}$ & 23 \\
\hline
\end{tabular}

Reference range (2.5 to 97.5 percentile).

PD: passive drooling; SS: stimulated salivation; RIA: radioimmunoassay. 


\section{CONCLUSION}

The use of saliva in laboratory testing has great potential, although it is still required to standardize some preanalytical variables, such as the collection system, taking into account the analyte to be quantified, the collection schedules, direct quantification of volume, sample recovery and prevention of sample contamination with blood from oral mucosa lesions.
The lack of correlation between some analytes present in saliva and blood does not preclude the possibility of using this fluid in laboratories, though it requires the establishment of specific reference intervals for these analyses through traditional methods, with minor modifications in the techniques to maximize sensitivity.

\section{RESUMO}

A utilização de saliva como alternativa para o diagnóstico de patologias e/ou monitoramento de atletas em competições ou treinos é muito atrativa devido à facilidade de obtenção da amostra e, principalmente, pela natureza menos invasiva que a coleta de sangue venoso. A saliva é um fluído hipotônico em relação ao plasma; contém compostos produzidos localmente nas glândulas salivares (imunoglobulina A [IgA] e $\alpha$-amilase), além de compostos difundidos do plasma (água, eletrólitos, proteínas, metabólitos e hormônios). A saliva desempenha funções importantes na proteção da mucosa oral contra microrganismos e na digestão dos alimentos. Sua produção e sua composição são dependentes da atividade do sistema nervoso autônomo simpático eparassimpático, cuja ação antagônica pode resultar em diferentes volumes de saliva com perfis proteico e iônico distintos. 0 objetivo da presente revisão é apresentar uma análise crítica das potencialidades e limitações da utilização da saliva como ferramenta diagnóstica para a medicina esportiva. Embora existam estudos que a utilizam para o monitoramento de atletas em situações de exercício e doping, ainda é necessário padronizar algumas variáveis pré-analíticas, como a escolba correta do melhor sistema de coleta, que permite quantificar facilmente o volume, com boa recuperação de amostra; os horários de coleta bem definidos, de acordo com as possíveis variações circadianas do analito; e a contaminação da saliva com sangue proveniente de lesões da mucosa oral, que tem de ser evitada. Outro ponto fundamental para aplicação no esporte éo estabelecimento de valores de referência para analitos quantificados na saliva, obtidos de uma população composta de sujeitos saudáveis e exercitados de forma constante e sistematizada, com progressão de cargas de esforço.

Unitermos: fluido oral; coleta de saliva; variáveis pré-analíticas; exercício; valores de referência.

\section{REFERENCES}

1. ALLGROVE, J. E. et al. Effects of exercise intensity on salivary antimicrobial proteins and markers of stress in active men. J Sports Sci, v. 26, n. 6, p. 653-61, 2008.

2. APS, J. K.; MARTENS, L.C. Review: the physiology of saliva and transfer of drugs into saliva. Forensic Sci Int, v. 150, p. 119-31, 2005.

3. AUBETS, J.; SEGURA, J. Salivary cortisol as a marker of competition related stress. Science \& Sports, v. 10, p. 149-54, 1995.

4. BISHOP, N.C.; GLEESON, M. Acute and chronic effects of exercise on markers of mucosa immunity. Front Biosci, v. 14, p. 4444-56, 2009.

5. BLANNIN, P. J. et al. The effect of exercising to exhaustion at different intensities on saliva immunoglobulin A, protein and electrolyte secretion. Int J Sports Med, v. 19, p. 546-52, 1998.

6. BLICHARZ, T. M. et al. Use of colorimetric test strips for monitoring the effect of hemodialysis on salivary nitrite and uric acid in patients with end-stage renal disease: a proof of principle. Clin Chem, v. 54, n. 9 , p. 1473-80, 2008.

7. CALVO, F. et al. Anaerobic threshold determination with analysis of salivary amylase. Can J Appl Physiol, v. 22, p. 553-61, 1997.

8. CARDOSO, E. M. L. et al. Assessment of salivary urea as a less invasive alternative to serum determinations. Scand J Clin Lab Invest, v. 69, n. 3, p. 330-4, 2009.

9. CHATTERTON, R. T. et al. Salivary alpha-amylase as a measure of endogenous adrenergic activity. Clin Physiol, v. 16, n. 4, p. 433-8, 1996.

10. CHIAPPIN, S. et al. Saliva specimen: a new laboratory tool diagnostic and basic investigation. Clin Chim Acta, v. 383, p. 30-40, 2007.

11. CHICHARRO, J. L. et al. Saliva composition and exercise. Sports Med, v. 26, n.1, p. 17-27, 1998.

12. CHICHARRO, J. L. et al. Saliva electrolytes as a useful tool for anaerobic threshold determination. Eur J Appl Physiol, v. 68, p.1495-7, 1994.

13. DE OLIVEIRA V. N. et al. Changes in the salivary biomarkers induced by an effort test. Int J Sports Med, v. 31, p. 377-81, 2010. 
14. DeCARO, J. A. Methodological considerations in the use of salivary a-amylase as a stress marker in field research. Am J Hum Biol, v. 20, p. 617-9, 2008.

15. DENNY, P. et al. The proteome of human parotid and submandibular sublingual gland salivas collected as the ductal secretions. J Proteome Res, v. 7, p. 1994-2006, 2008.

16. FOX, P. C. Xerostomia: evaluation of a symptom with increasing significance. JAm Dent Assoc, v. 110, n. 4, p. 519-25, 1985.

17. GALLAGHER, P. et al. Assessing cortisol and dehydroepiandrosterone (DHEA) in saliva: effects of collection method. J Psychopharmacol, v. 20, n. 5, p. 643-9, 2006.

18. GLEESON, M.; PYNE, D. B. Exercise effects on mucosa immunity. Immunol Cell Biol, v. 78, p. 536-44, 2000.

19. GONZALEZ, D.; MARQUINA, R.; RONDÓN, N. Effects of aerobic exercise on uric acid, total antioxidant activity, oxidative stress, and nitric oxide in human saliva. Res Sports Med, v. 16, p.128-37, 2008.

20. GRANGER, D. A. et al. Salivary $\alpha$-amylase in biobehavioral research. Ann NY Acad Sci, v. 1098, p. 122-44, 2007.

21. GRÖSCHL, M. Current status of salivary hormone analysis. Clin Chem, v. 54, n. 11, p. 1759-69, 2008.

22. GRÖSCHL, M. et al. Evaluation of saliva collection devices for the analysis of steroids, peptides and therapeutic drugs. J Pharma Biomed Anal, v. 47, p. 478-86, 2008.

23. HANSEN, A. M. et al. Evaluation of a radioimmunoassay and establishment of a reference interval for salivary cortisol in healthy subjects in Denmark. Scand J Clin Lab Invest, v. 63, p. 303-10, 2003.

24. HANSEN, A. M.; GARDE, A. H.; PERSSON, R. Sources of biological and methodological variation in salivary cortisol and their impact on measurement among healthy adults: a review. Scand J Clin Lab Invest, v. 68 , n. 6 , p. 448-58, 2008.

25. HU, S. et al. Large scale identification of proteins in human salivary proteome by liquid chromatography/mass spectrometry and twodimensional gel electrophoresis mass spectrometry. Proteomics, v. 5 , p. 1714-28, 2005.

26. HUANG, C. M. Comparative proteomic analysis of human whole saliva.Arch Oral Biol, v. 49, n.12, p. 951-62, 2004.

27. HUMPHREY, S. P.; WILLIAMSON, R.T. A review of saliva: normal composition, flow, and function.J Prosthet Dent, v. 85, n. 2, p. 162-9, 2001.

28. JOU, Y. J. et al. Proteomic identification of salivary transferrin as a biomarker for early detection of oral cancer. Anal Chim Acta, v. 681, p. 41-8, 2010.

29. KALK, W. W. I. et al. Sialometry and sialochemistry: a non-invasive approach for diagnosing Sjögren's syndrome. Ann Rheum Dis, v. 61, p. 137-44, 2002.

30. KAUFMAN, E.; LAMSTER, I. B. The diagnostic application of saliva. Crit Rev Oral Biol Med, v. 13, n. 2, p. 197-202, 2002.

31. KRAEMER, W.J.; RATAMESS, N. A. Hormonal responses and adaptations to resistance exercise and training. Sports Med, v. 35, n. 4, p. 339-61, 2005. 32. LANGMAN, L.J. The use of oral fluid for therapeutic drug management. Ann NY Acad Sci, v. 1098, p.145-66, 2007.

33. LEVINE, M. J. Salivary macromolecules. A structure/function synopsis. Ann N Y Acad Sci, v. 20, n. 694, p. 11-6, 1993.
34. LI, T. L.; GLEESON, M. The effect of single and repeated bouts of prolonged cycling and circadian variation on saliva flow rate, immunoglobulin A and-amylase responses. J Sports Sci, v. 22, p. 1015-24, 2004.

35. LIPPI, G. et al. Measurement of morning saliva cortisol in athletes. Clin Biochem, v. 42, p. 904-6, 2009.

36. McDOWELL, S. L. et al. The effect of exercise intensity and duration on salivary immunoglobulin A. Eur J Appl Physiol, v. 63, p.108-11, 1991. 37. MICHISHIGE, F. et al. Effect of saliva collection method on the concentration of protein components in saliva. J Med Invest, v. 53, p.140-6, 2006.

38. NAGLER, R. M. et al. Characterization of the differentiated antioxidant profile of human saliva. Free Radic Biol Med, v. 32, n. 3, p. 268-77, 2002

39. NATER, U. M. et al. Determinants of the diurnal course of salivary alpha-amylase. Psychoneuroendocrinology, v. 32, p. 392-401, 2007.

40. NATER, U. M. et al. Human salivary alpha-amylase reactivity in a psychosocial stress paradigm. Int J Psychophysiol, v. 55, n. 3, p. 333-42, 2005.

41. NATER, U. M.; ROHLEDER, N. Salivary alpha-amylase as a noninvasive biomarker for the sympathetic nervous system: current state of research. Psychoneuroendocrinology, v. 34, p. 486-96, 2009.

42. NIEMAN, D. C. et al. Change in salivary IgA following a competitive marathon race. Int J Sports Med, v. 23, p. 69-75, 2002.

43. NIEUW AMERONGEN, A.V.; LIGTTENBERG, A. J.; VEERMAN, E. C. Implications for diagnostics in the biochemistry and physiology of saliva. Ann NY Acad Sci, v. 1098, p. 1-6, 2007.

44. NUNES L. A. S. et al. Adequacies of skin puncture for evaluating biochemical and hematological parameters in athletes. Clin J Sport Med, v.16, n. 5, p. 418-21, 2006.

45. NUNES L. A. S. et al. Reference intervals for saliva analytes collected by a standardized method in a physically active population. Clin Biochem, v. 44, p. 1440-4, 2011.

46. OHKUWA, T. et al. Salivary and blood lactate after supramaximal exercise in sprinters and long distance runners. Scand J Med Sci Sports, v. 5 , p. 285- $90,1995$.

47. OWEN-SMITH, B.; QUINEY, J.; READ, J. Salivary urate in gout, exercise and diurnal variation. Lancet, v. 351, n. 27, p. 1932, 1998.

48. PATEL, R. S. et al. Production of gender-specific morning salivary cortisol reference intervals using internationally accepted procedures. Clin Chem Lab Med, v. 42, n. 12, p. 1424-9, 2004.

49. RAGGAM, R. B. et al. Evaluation of a novel standardized system for collection and quantification of oral fluid. Clin Chem Lab Med, v. 46, n. 92, p. 287-91, 2008.

50. RAGGAM, R. B. et al. Reliable detection and quantification of viral nucleic acids in oral fluid: liquid phase-based sample collection in conjunction with automated and standardized molecular assays. J Med Virol, v. 80, p. 1684-8, 2008.

51. RA0 P. V.et al. Proteomic identification of salivary biomarkers of type2 diabetes.J Proteome Res, v. 8, n. 1, p. 239-45, 2009.

52. REHAK, N. N.; CECCO, S. A.; CSAKO, G. Biochemical composition and electrolyte balance of "unstimulated" whole human saliva. Clin Chem Lab Med, v. 38, n. 4, p. 335-43, 2000. 
53. SAPOLSKY, R. M.; ROMERO, L. M.; MUNCK, A. U. How do glucocorticoids influence stress responses? Integrating permissive, suppressive, stimulatory, and preparative actions. Endocr Rev, v. 21, p. 55-89, 2000.

54. SCHWARTZ, E. B.; GRANGER, D. A. Transferrin enzyme immunoassay for quantitative monitoring of blood contamination in saliva. Clin Chem, v. 50 , n. 3, p. 546-55, 2004.

55. STRANO-ROSSI, S. et al. Analysis of stimulants in oral fluid and urine by gas chromatography-mass spectrometry II: pseudoephedrine. J Anal Toxicol, v. 34, n. 4, p. 210-5, 2010.

56. TRILCK, M. et al. Salivary cortisol measurement - a reliable method for diagnosis of cushing's syndrome. Exp Clin Endocrinol Diabetes, v. 113, p. 225-30, 2005.
57. URHAUSEN, A.; KINDERMANN, W. Diagnosis of overtraining. What tools do we have? Sports Med, v. 32, n. 2, p. 95-102, 2002.

58. VINING, R. F.; McGINLEY, R. A.; SYMONS, R. G. Hormones in saliva: mode of entry and consequent implications for clinical interpretation. Clin Chem, v. 29, n. 10, p. 1752-6, 1983.

59. WALSH, N. P. et al. Salivary IgA response to prolonged exercise in a cold environment in trained cyclists. Med Sci Sports Exerc, v. 34, p.1632-7, 2002

60. WONG, D. T. Salivary diagnostics powered by nanotechnologies, proteomics and genomics. JADA, v. 137, p. 313-21, 2006.

61. YOUSSEF, H. et al. Comparison of total antioxidant capacity of salivary, capillary and venous samplings: interest of the salivary total antioxidant capacity on triathletes during training season.J Sports Med Phys Fitness, v. 48, p. 522-9, 2008.

\section{MAILING ADDRESS}

Lázaro Alessandro Soares Nunes

Rua Monteiro Lobato, s/n; Instituto de Biologia; Departamento de Bioquímica, sala 12; Barão Geraldo; CEP: 13083-970; Campinas-SP; Brazil; e-mail: lazaroalessandro@yahoo.com.br. 